\title{
Effect of gibberellic acid on the quality of chrysanthemum (Dendranthema grandiflora L.) cv. Faroe
}

\section{Marcos Ribeiro da Silva Vieira ${ }^{* 1}$, Giuseppina Pace Pereira Lima ${ }^{2}$, Angela Vacaro de Souza', Paula Nepomuceno Costa ${ }^{1}$, Caio Marcio Guimarães Santos ${ }^{1}$, Leonardo de Sousa Alves ${ }^{3}$ and Nelson Geraldo de Oliveira'}

\footnotetext{
${ }^{1}$ Universidade Estadual Paulista, Departamento de Produção Vegetal (Horticultura), CEP: 18601-060, Botucatu, SP, Brasil.

${ }^{2}$ Universidade Estadual Paulista, Departamento de Química e Bioquímica, Instituto de Biociências, Botucatu-SP, Brasil.

${ }^{3}$ Universidade Federal de Campina Grande, Pombal, PB, Brasil.
}

\section{Accepted 27 October, 2011}

\begin{abstract}
The aim of the present work was to evaluate the quality of chrysanthemum cultivar Faroe, subjected to different gibberellic acid $\left(\mathrm{GA}_{3}\right)$ concentrations applied to the field. The treatments were composed of four doses of $\mathrm{GA}_{3}\left(0,15,30\right.$ and $\left.45 \mathrm{mg} \mathrm{L}^{-1}\right)$ applied at the beginning of the formation of buttom floral (28 days after transplanting of seedlings). According to the results, a single low concentration of $\mathrm{GA}_{3}$ application did not interfere with the phenotypic characteristics of the chrysanthemum cultivar Faroe.
\end{abstract}

Key words: Dendranthema grandiflora, height, diameter, flowering.

\section{INTRODUCTION}

The use of plant growth regulators has been highlighted as a very common practice in agriculture. According to Tan and Marbach (2000), plant growth regulators are organic substances with important functions in regulating growth, and acting as inhibiting stimulants, depending on its concentration and other intrinsic characteristics of the plant. Among the groups with the possibility of hormone use is exogenous gibberellin (Taiz and Zeiger, 2004). Gibberellic acid $\left(\mathrm{GA}_{3}\right)$ has been used to increase the length or height of plants, increase the number of flowers and induce flowering (Medina and Saavedra, 1999; Taiz and Zeiger, 2004).

According to some works, it is possible to note the efficiency of application of $\mathrm{GA}_{3}$ in the field of quality flowers. Sung and Chang (2000) observed in rhododendron (Rhododendron pulchrum) that the application of $\mathrm{GA}_{3}$ was effective on the growth of buds and flowers per plant.

${ }^{*}$ Corresponding author. E-mail: m.r.s.v@hotmail.com.

Abbreviations: $\mathbf{G A}_{3}$, Gibberellic acid; $\mathbf{A B A}$, abscisic acid.
Blázquez et al. (2002) observed the early flowering by $\mathrm{GA}_{3}$ application, especially in short-day plants of the genus Arabidopsis. The times of application and use of the concentration of $120 \mathrm{mg} \mathrm{L}^{-1}$ gibberellic acid $\left(\mathrm{GA}_{3}\right)$ affected the stem diameter of chrysanthemum cultivar Yoko ono (Vieira et al., 2011). Bulbous plants, such as dahlia (Khan and Tewari, 2003), revealed an increase in height on the stems at different concentrations. In Anthurium (Anthurium andreanum), these applications were neither able to increase the height, nor stimulate flowering stage (Wang et al., 1999). Similar results were observed for Al-khassawneh et al. (2006) on growth and flowering of Iris nigricans Dinsm.

The results of the studies on the effectiveness of $\mathrm{GA}_{3}$ on flowers are contradictory. Thus, the objective of this study was to evaluate the use of low concentrations of $\mathrm{GA}_{3}$ applied to the field on the phenotypic characteristics of the stems of chrysanthemum cultivar Faroe.

\section{MATERIALS AND METHODS}

The experiment was conducted in plastic greenhouses in Cordei- 


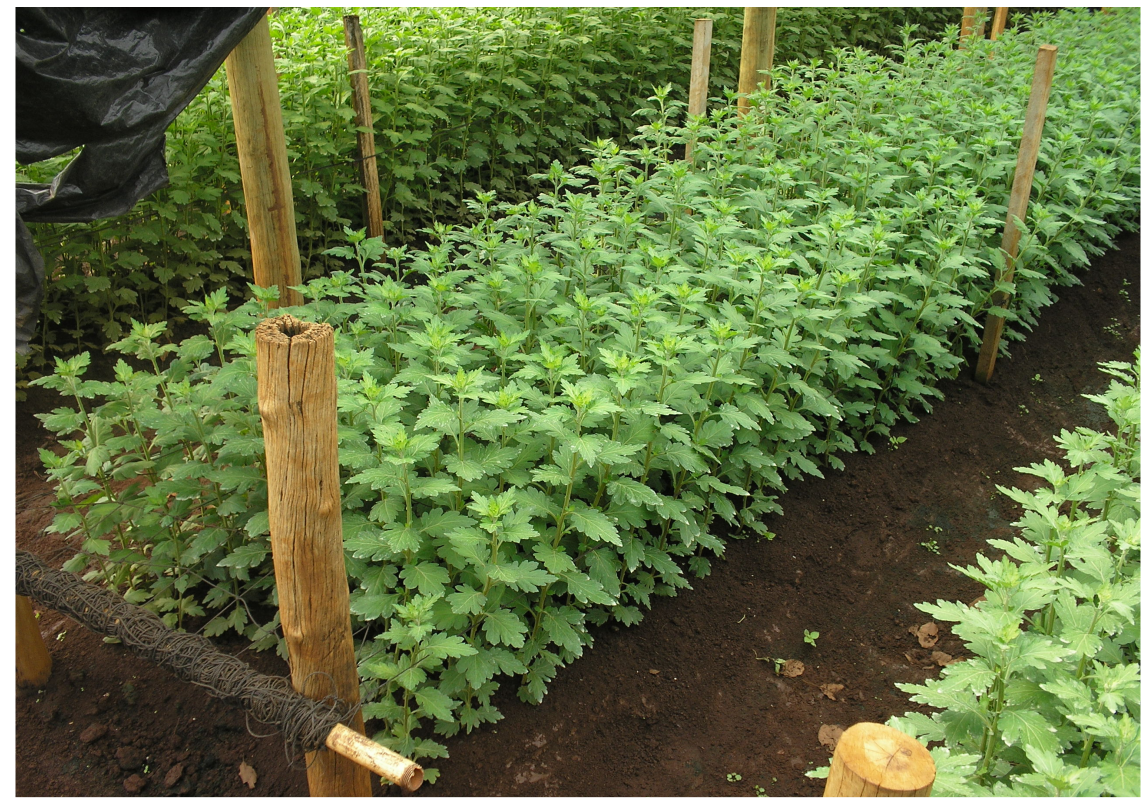

Figure 1. Formation of floral buttom.

rópolis, São Paulo, Brazil (22²8' 55" S, 47²7' 24" W). Medium sized seedlings of chrysanthemum (Dendranthema grandiflora Tzvelev) cultivar Faroe were used and were characterized by dichotomous leaves with alternate disposition on the stem, and a globular inflorescence formed by small white petals, but not visible internal disk flowers. In the cultivation conditions of Cordeirópolis, plants were cultivated for $71 / 2$ weeks for flower induction.

The experimental design was randomized blocks, each containing four plots. Treatments were composed of four doses $(0$, 15,30 and $45 \mathrm{mg} \mathrm{L}^{-1}$ ) of $\mathrm{GA}_{3}$ (Pro-Gibb ${ }^{\circledR}-10 \%$, Valent). $\mathrm{GA}_{3}$ was applied at the beginning of flower bud formation (28 days after transplanting of seedlings). Plants (stems) were sprayed in the morning with $100 \mathrm{ml}$ of each concentration for each treatment (Figure 1). Experiments were carried out on 40 plants for each treatment (cultivated at a density of 64 plants $/ \mathrm{m}^{2}$ ) with four replicates, after which plants on the borders were discarded. In all the treatments, $30 \mathrm{ml} / 100 \mathrm{~L}^{-1}$ of a non-ionic surfactant (Extravon ${ }^{\circledR}$, Syngenta Agro S/A) was used to improve wetting, and spray distribution was added. The apparatus used for $\mathrm{GA}_{3}$ application was a $\mathrm{CO}_{2}$ backpack tank equipped with a sprayer nozzle-shaped fan.

The flowers were harvested at approximately $95 \%$ of ligules expanded (Figure 2). Immediately after harvest, the height and stem diameter were analyzed, and the flower diameter, ligule length, number of flowers and reaction time (induction of flowering) of the 12 stems were identified within each parcel of each treatment. To measure the height of the stem, we used a tape made in inches, and a caliper reading of stem diameter. The parameters, flower diameter and length of ligule, were measured by a ruler in centimetre, and the number of flowers and reaction time (induction of flowering) was measured by counting the days after transplanting of seedlings.

Analysis of variance was performed to detect differences between treatment means, which were separated by Tukey's test ( $P$ $<0.05$ ) using SAS software.

\section{RESULTS AND DISCUSSION}

According to Table 1, no significant effect was observed for the different concentrations of $\mathrm{GA}_{3}$ on the phenotypic characteristics of stems of chrysanthemum cultivar Faroe. One factor that may not have contributed to stem height is the time of application. Since the plants were sprayed at a time not earlier than 28 days after transplanting of the seedlings, it did not differ between treatments after harvest (86 days), with an average height of $113.06 \mathrm{~cm}$. According to Grzesil (1989), $\mathrm{GA}_{3}$ application in order to stretch the stem may be more related to the time of application than the product concentration. Schmidt et al. (2003) observed in chrysanthemum cultivar Viking that when applications were made early, the effect on final height of the stems was even more pronounced with the use of lower concentrations.

Besides the time of application, the type of gibberellin can be more active in a plant than in another (Taiz and Zeiger, 2004), as well as the concentration used and the number of applications (Mielke, 2005). In Better rose, an application of $\mathrm{GA}_{3}$ at concentrations of 10 to $100 \mathrm{mg} \mathrm{L}^{-1}$ increased the stem height and weight of fresh cut flowers (Castro, 1998). In Hemerocallis hybrid 'Graziela Barroso', the results indicated that the optimal number of applications went up twice, differing statistically from all other applications (Ottmann, 2006). The balance between the hormones is a factor that can determine the effectiveness of a hormone alone or when grouped. Taiz and Zeiger (2004) assumed that the increase in plant height can be attributed to auxin because it can induce the synthesis of gibberellins and vice versa, and can also cause cell elongation. Tawar et al. (2003) noted an increase in the stem height of Gladiolus 'Jester', with applications of $\mathrm{GA}_{3}\left(100,150,200\right.$ and $\left.250 \mathrm{mg} \mathrm{L}^{-1}\right)$, indole-3-acetic acid (IAA, 100 and $250 \mathrm{mg} \mathrm{L}^{-1}$ ) and $\mathrm{N}^{6}$ benzyl adenine 


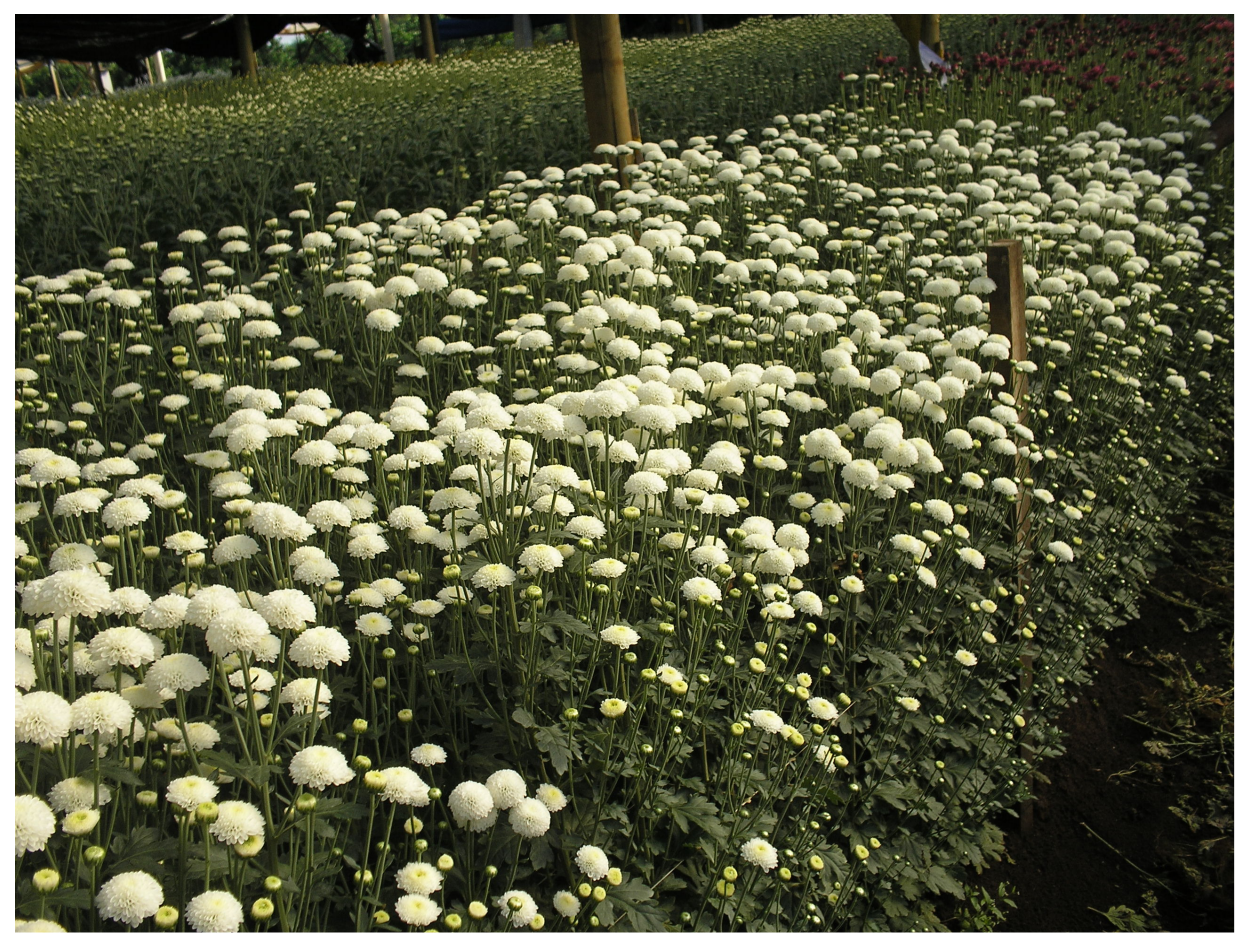

Figure 2. Harvest of chrysanthemum Faroe.

Table 1. Phenotypic characteristics of chrysanthemum Faroe in response to the applied gibberellic acid $\left(G A_{3}\right)$ in the field; Cordeirópolis (SP), 2007.

\begin{tabular}{ccccccc}
\hline \multirow{2}{*}{$\mathrm{GA}_{3}\left(\mathbf{m g ~ L}^{-1}\right)$} & \multicolumn{7}{c}{ Fenometric parameter } \\
\cline { 2 - 7 } & $\mathbf{A h}(\mathbf{c m})$ & $\mathbf{D h}(\mathbf{c m})$ & $\mathbf{D f}(\mathbf{c m})$ & $\mathbf{C l}(\mathbf{c m})$ & $\mathbf{N f}$ & $\mathbf{C c}$ (days) \\
\hline 0 & $112.57^{\mathrm{a}}$ & $0.5136^{\mathrm{a}}$ & $4.973^{\mathrm{a}}$ & $1.15^{\mathrm{a}}$ & $16.0^{\mathrm{a}}$ & $53^{\mathrm{a}}$ \\
15 & $112.96^{\mathrm{a}}$ & $0.5138^{\mathrm{a}}$ & $4.962^{\mathrm{a}}$ & $1.15^{\mathrm{a}}$ & $16.0^{\mathrm{a}}$ & $53^{\mathrm{a}}$ \\
30 & $113.25^{\mathrm{a}}$ & $0.5133^{\mathrm{a}}$ & $4.974^{\mathrm{a}}$ & $1.16^{\mathrm{a}}$ & $15.0^{\mathrm{a}}$ & $53^{\mathrm{a}}$ \\
45 & $113.48^{\mathrm{a}}$ & $0.5171^{\mathrm{a}}$ & $4.973^{\mathrm{a}}$ & $1.15^{\mathrm{a}}$ & $16.0^{\mathrm{a}}$ & $53^{\mathrm{a}}$ \\
$\mathrm{Mean}$ & 113.06 & 0.514 & 4.973 & 1.15 & 15.75 & 53 \\
$\mathrm{CV} \%$ & 4.86 & 6.43 & 5.06 & 4.71 & 5.89 & - \\
\hline
\end{tabular}

Ah, stem height; Dh, stem diameter; Df, flower diameter; $\mathrm{Cl}$, ligule length; Nf, number of flower; Cc, induction flower. Means followed by same column do not differ by Tukey's test $(0.05 \%)$.

(BA, 50 and $100 \mathrm{mg} \mathrm{L}^{-1}$ ), and found that this increase followed the concentration of the respective plant growth regulators. However, high concentrations may also cause an increase in height, which can compromise the product at the time of distri-bution (Khan and Tewari, 2003).

In this study, a comparison of the control with the other treatments showed no change in stem diameter, with an average of $0.514 \mathrm{~cm}$; although, the study of GulewskaKulikowski et al. (2000) was conditioned upon the exogenous application of gibberellin beyond the structure, the site of action and the sensitivity of the target organ. This means that the role played by gibberellins in the control of phase change is complex, varying among species and involving interactions with other factors (Taiz and Zeiger, 2004). Schmidt et al.
(2003), working with chrysanthemum cultivar Viking in a concentration of $200 \mathrm{mg} \mathrm{L}^{-1}$, reported that applications made for the fourth week after planting showed minor changes, while for applications made in the second week, there was no change in the diameter of the stem. Analyzing the diameter of the flower with a mean of 4.97 $\mathrm{cm}$, this characteristic was not significantly influenced by concentrations of $\mathrm{GA}_{3}$. This response referred to the slow growth of chrysanthemum flower disk Faroe, since there were no differences in the length of ligules, averaging $1.15 \mathrm{~cm}$.

However, Bellé et al. (2006) working with the chrysanthemum cultivar Gompier observed small differences in the reduction of flower diameter. According to the same author, this reduction was not higher, because some 
concentrations of $\mathrm{GA}_{3}$ were applied, at most, twice. This situation of minimal differences in flower diameter in response to $\mathrm{GA}_{3}$ and control photoperiod was also observed by Mello (2003).

In the literature, we observed that $\mathrm{GA}_{3}$ generally caused an increase in the number of flower buds or the number of flowers or inflorescences. Contrary to the results of this work, where the average value found in chrysanthemum cultivar Faroe was 15.75 buds per stem, there was no significant difference between treatments. In podophylum Syngonium Schott 'White Butterfly' treated with $\mathrm{GA}_{3}\left(0,10,20,40\right.$ and $\left.80 \mathrm{mg} \mathrm{L}^{-1}\right)$, the best average number of flowers per plant (2.4) occurred in the treatment with $80 \mathrm{mg} \mathrm{L}^{-1}$, when compared to the control treatment (Henny et al., 1999). However, a lower value was found in Hemerocallis hybrida 'Graziela Barroso' in the third application of $\mathrm{GA}_{3}$, which produced 2.93 buds per plant (Ottmann, 2006). In strawberry (Fragaria $x$ ananassa Duch. cultivars Seascape, Laguna and Camarosa) sub-jected to three concentrations of $\mathrm{GA}_{3}(0$, 50 and $200 \mathrm{mg} \mathrm{L}^{-1}$ ), the best result for the number of flower buds and open flowers was found in the concentration of $50 \mathrm{mg} \mathrm{L}^{-1} \mathrm{GA}_{3}$ in cultivar Seascape (Paroussi et al., 2002). In gerbera (Gerbera jamesonii), there was an increase in the number of flowers per plant through the application of $\mathrm{GA}_{3}$ at concentrations of 50 and $100 \mathrm{mg} \mathrm{L}^{-1}$ (Nair et al., 2002).

Dedranthema Tzevelev grandiflora 'Viking' (cut chrysanthemum / short-day plant) under four application times $(2,4,8$ and 10 weeks after the experimental period in summer / autumn), and $\mathrm{GA}_{3}(0,100,200$ and $300 \mathrm{mg}$ $\mathrm{L}^{-1}$ ) showed no significant difference between the concentrations of $\mathrm{GA}_{3}$ to the number of flowers (Schmidt et al., 2003). These controversial results corroborate the assertion quoted earlier that the effect of a growth-regulating substance depends on the concentration, number and timing of application; although, the stage of plant growth and species or the cultivar treated also depends on environmental factors (Pereira and Adams, 1996).

According to Rodrigues and Leite (2004), environmental conditions affect the biosynthesis of gibberellins, and their occurrence in long days usually increased production of gibberellins than in short days. Moreover, the difference between daytime and nighttime temperatures may influence the levels of endogenous gibberellin (Thingnaes et al., 2003).

The cut chrysanthemum Faroe precocity was not obtained in the different treatments $(0,15,30$ and $45 \mathrm{mg}$ $\left.\mathrm{L}^{-1}\right)$. Under the conditions of Cordeirópolis (SP), it was observed that the reaction time (induction to flowering) to harvest was 53 days (7.5 weeks) on average. These results suggest that the regulation of flowering may be associated with specific GAs, but they do not prove that GA is the hypothetical flowering hormone. In fact, a certain level of GA is probably required for flowering and initiation of flower stalks in some species, but other routes are also needed so that this event occurs (Taiz and Zeiger, 2004). Several studies have confirmed the earliness of flowering by $\mathrm{GA}_{3}$ application. In the cyclamen, Concerto Scarlet 'Caruso' ${ }^{\circledR}$ at a concentration of $45 \mathrm{mg}$ $\mathrm{L}^{-1}$ was the one with the larger plant precocity (Mielke, 2005). The application of $\mathrm{GA}_{3}$ also accelerated flowering in $x$ Limonium 'Misty Blue' when compared to the control, giving a higher percentage between 8 and $12.6 \%$ as compared to untreated plants (Garner and Armitage, 1996). Kamuro et al. (2001) studied the effect of a single application of $\mathrm{GA}_{3}$ and abscisic acid in various proportions in the flowering plants of spinach, a long-day plant (LDP) in non-inductive periods (shorter days), and the best results for flowering (70 to 100\%) were found in the proportions of $1: 5 \mathrm{mg} \mathrm{L}^{-1}$ and $5: 5 \mathrm{mg} \mathrm{L}^{-1} \mathrm{ABA} / \mathrm{GA}_{3}$.

$A$ model that has been postulated in this study shows that the flowering process would be regulated by several molecules, including gibberellins, cytokinins, sucrose and polyamines (Bewley et al., 2000). Moreover, Bernier et al. (1993) assumed that the mineral nutrition and water stress may play a secondary role in floral induction.

\section{Conclusions}

The use of low concentrations of $0,15,30$ and $45 \mathrm{mg} \mathrm{L}^{-1}$ gibberellic acid $\left(\mathrm{GA}_{3}\right)$ in a single application had no interference with the phenotypic characteristics of the stems of chrysanthemum cultivar Faroe, demonstrating the low action of gibberellin applied in the field.

\section{REFERENCES}

Al-Khassawneh NM, Karma NS, Civil RA (2006). Growth and flowering of black Iris (Iris nigricans Dinsm.) following treatment with plant growth regulators: Amsterdam. Sci. Horticult. 107: 187-193.

Bellé RA, Hempel FD, McCormick S, Zambryski P (2007). Gibberellc acid and short Day interrupted in cut chrysanthemum (Dendranthema grandiflora, Tzvelev, "Gompier Chá") Ciência Rural, Santa Maria. $37(2)$.

Bewley JD, Hempel FD, McCormick S, Zambryski P (2000). Reproductive development. In: Buchanan BB, Gruissem W, Jones RL. Maryland: Buchanan BB, Gruissem W, Jones RL, Biochem. Mol. Biol. Plants. 988: 1043.

Blásquez MA, Trénor M, Weigel D (2002). Independent control of gibberellin biosintesis and flowering time by the circadian clock in Arabidopsis. Bethesda, Plant Physiol.130: 1771-1775.

Castro PRC (1998). Utilização de reguladores vegetais na fruticultura, na olericultura e em plantas ornamentais. Série produtor Rural, Ed. especial, Piracicaba: ESALQ- Divisão de Biblioteca e Documentação. pp. 81-84.

Chang YS, Sung FH (2000). Effects of gibberellic acid and dormancybreaking chemicals on flower development of Rhododendron pulchrum Sweet and R. scabrum Don. Amsterdam, Sci. Horticult. 83: 331-337.

Garner MJ, Armitage AM (1996). Gibberellin applications influences the scheduling and flowering of Limonium x 'Misty Blue'. Alexandria. Hortscience, 2: 247-248.

Grzesik M (1989). Factors influencing the effectiveness of growth regulators in nursery production. Wageningen, Acta Horticult. 251: 371-375.

Gulewska-Kulikowska H, Majewska M, Kopcewicz J (2000). Gibberellins in the control flower transition in Pharbitis nil. Ireland, Physiol. Planta. 108: 202-207. 
Henny RJ, Norman DJ, Kane ME (1999). Gibberellic acid-induced flowering of Syngonium podophyllum Schott 'White Butterfly'., Alexandria, Hortscience, 34(4): 676-677.

Kamuro Y, Agyeman SO, Matsui S (2001). The promotive effect of applying mixtures of (S)- (+)- abscisic acid and gibberellic acid in flowering in long-day plants. Dordrecht, Plant Growth Regul. 33:189194.

Khan FU, Tewari GN (2003). Effect of growth regulators on growth and flowering of dahlia (Dahlia variabilis L.). Bangalore, Indian J. Horticult. 60(2): 192-194.

Medina EO, Saavedra AL (2005). El uso de regulador de crecimiento en la floricultura mexicana. Ciência y Desarrollo, Disponível em: <http://www.conacyt.mx/secobi/bancos/cyd/pdf/148-26.pdf> Acesso em 10 abr. Bogotá. 148: 1-17.

Mello JB (2003). Uso do ácido giberélico e dias curtos interrompidos em crisântemo de corte (Dendranthema grandiflora Tzvelev.) "Calábria" e "Lameet Bright. Santa Maria: Universidade Federal de Santa Maria. Dissertação de Mestrado. p. 66.

Mielke CE (2005). Precocidade e qualidade de Ciclâmen após a aplicação de giberelina. Curitiba: Universidade Federal do Paraná. Dissertação de Mestrado. p. 93.

Nair SA, Singh V, Sharma TVRS (2002). Effect of plant growth regulators on yield and quality of gerbera under Bay Island conditions. Bangalore. Indian J. Horticult. 59(1)):100-105.

Ottmann AAM (2006). Induction of flowering hemerocallis hybrida cv. Graziela Barros After gibberellic acid $\left(\mathrm{GA}_{3}\right)$. (Máster in Production vegetal) - Universidade Federal Curitiba. p. 69.

Paroussi G, Voyatzis DG, Parroussi E, Drogoudi PD (2002). Growth, flowering and yield responses to $\mathrm{GA}_{3}$ of strawberry grown under different environmental conditions. Amsterdam. Sci. Horticult. 96: 103-113.

Rodrigues TDJ, Leite IC (2004). Fisiologia vegetal-hormônios das plantas. Jaboticaba. pp. 19-37.
Schmidt C, Bellé AB, Nardi C, Toledo AK (2003). The gibberellic acid $\left(\mathrm{GA}_{3}\right)$ in the cut chrysanthemum (Dedranthema grandiflora Tzevelev.) viking: planting summer/autumn. Revista Ciência Rural, 33(2): 14511455.

Taiz L, Zeiger E (2004). Fisiologia vegetal. 3. Ed, p. 720.

Tawar RV, Sable AS, Giri MD (2003). Effect of growth regulators on growth and flowering of Gladiolus (cv. Jester). Índia Ann. Plant Physiol. 16(2): 109- 111.

Thingnaes E, Torre S, Ernstsen A, Moe R (2003). Day and night temperature responses in Arabidopsis: Effects on gibberellin and auxin content, cell size, morphology and flowering time. London. Ann. Bot. 92(4): 601-612.

Vieira MRS, Souza AV, Santos CMG, Alves LS, Cerqueira RC, Paes RA, Souza AD, Fernandes LMS (2011). Stem diameter and height of chrysanthemum cv Yoko ono as affected by gibberellic acid. Afri. J. Biotechnol. 56(10): 11943-11947. 